\title{
Comparing efficiency of public universities among European countries: Different incentives lead to different performances
}

Citation for published version (APA):

Agasisti, T., \& Haelermans, C. (2016). Comparing efficiency of public universities among European countries: Different incentives lead to different performances. Higher Education Quarterly, 70(1), 81-104. https://doi.org/10.1111/hequ.12066

Document status and date:

Published: 01/01/2016

DOI:

10.1111/hequ.12066

Document Version:

Publisher's PDF, also known as Version of record

Document license:

Taverne

Please check the document version of this publication:

- A submitted manuscript is the version of the article upon submission and before peer-review. There can be important differences between the submitted version and the official published version of record.

People interested in the research are advised to contact the author for the final version of the publication, or visit the DOI to the publisher's website.

- The final author version and the galley proof are versions of the publication after peer review.

- The final published version features the final layout of the paper including the volume, issue and page numbers.

Link to publication

\footnotetext{
General rights rights.

- You may freely distribute the URL identifying the publication in the public portal. please follow below link for the End User Agreement:

www.umlib.nl/taverne-license

Take down policy

If you believe that this document breaches copyright please contact us at:

repository@maastrichtuniversity.nl

providing details and we will investigate your claim.
}

Copyright and moral rights for the publications made accessible in the public portal are retained by the authors and/or other copyright owners and it is a condition of accessing publications that users recognise and abide by the legal requirements associated with these

- Users may download and print one copy of any publication from the public portal for the purpose of private study or research.

- You may not further distribute the material or use it for any profit-making activity or commercial gain

If the publication is distributed under the terms of Article $25 \mathrm{fa}$ of the Dutch Copyright Act, indicated by the "Taverne" license above, 


\title{
Comparing Efficiency of Public Universities among European Countries: Different Incentives Lead to Different Performances
}

\author{
Tommaso Agasisti, Politecnico di Milano, \\ tommaso.agasisti@polimi.it \\ and Carla Haelermans, Maastricht University, \\ carla.haelermans@maastrichtuniversity.nl
}

\begin{abstract}
This paper analyses the relationship between the public funding systems of higher education in Italy and the Netherlands and their universities' performances. Empirically, an efficiency analysis on 13 Dutch and 58 Italian public universities is conducted. The findings show that the relative efficiency of Italian and Dutch universities is strongly influenced by the policy perspective adopted. If the goal is to realise the European goals and minimise resources employed for obtaining a high number of graduates, Dutch universities turn out to be more efficient. However, Italian universities are much more efficient if the priority is to minimise the costs for a given level of activity, such as number of students.
\end{abstract}

\section{Introduction}

Higher education is deemed a very important matter in international politics; and so it is for Europe as well. The European Union stresses the importance of higher education in the targets posed for the so-called 'EU2020 strategy', which states that there should be a high share of highly educated people in Europe by 2020, as well as an increase in innovation, which is fostered by universities' research, among others (Heuse and Zimmer, 2011; EU2020, 2014). Although not all policy objectives are similarly specific in nature, at several occasions over the last five-to-ten years, some very specific targets were set by the European Commission; for example, 'at least $40 \%$ of 30-34-year-olds having completed third-level education by 2020 in each member country' and 
these specific targets should be aimed for by the European member states. To stimulate higher education institutions to improve their results and to achieve these goals as a country, the governments in many European countries reallocated recurrent public funds to universities with newly developed performance-based models (Jongbloed and Vossensteyn, 2001), using several performance indicators as a condition for receiving funding.

However, there are several challenges to achieving the European targets as described above. The first challenge is that the European Union does not have the power to directly regulate the European higher education sector but is highly dependent on the national policies to achieve its European own goals. This is because the European Union cannot make national policies but only provides guidelines for the development of these policies, and the goals that should be aimed for, by its member states. The second challenge is that the (newly) developed performance-indicators are not the same across countries. In some countries, such as Spain, Italy, United Kingdom and France, the funds each university receives are based on the number of students or other input measures, whereas in some other countries (the Netherlands, Denmark, Finland) the model is much more performance-oriented and considers indicators such as the number of diplomas, credits or graduates (Jongbloed, 2008). Given that universities are highly dependent on national funding, one can argue that funding rules (partly) define the course of a universities' policy plan and thereby its performance indicators.

In the light of choosing the best instruments for regulation, it is important to understand whether the funding rules are indeed able to influence universities' performances: and a cross-country comparison between countries that have different funding models seems a viable way to test this.

Therefore, the main research question discussed in this paper is as follows: is there a relationship between the public funding model adopted in a country and the performance of its universities?

The second research question following from this is what can the European Commission learn from these different national allocation models with respect to its aim to achieve the EU2020 targets?

In this paper, performance is defined as the performance indicators set by the relevant countries, which means successful grant applications for both types of countries but number of students in the one group of countries and number of graduates in the other group of countries. However, the number of graduates (bachelor, master and $\mathrm{PhD}$ 
graduates) is more commonly accepted as performance, as universities actually have to achieve something to turn starting students into graduates (in comparison to just being able to attract a large amount of students starting university).

In the analysis, performance is measured by using efficiency analysis (Johnes, 2004). In the light of this approach, it is particularly relevant to pay attention to the relationship between inputs and outputs of the higher education institutes, more than to their overall or absolute performance. Indeed, in efficiency analyses, institutes are compared to the best-practice units, based on their ability of maximising the outputs given the available inputs, or conversely reducing the inputs employed to obtain a given level of output. This way of conducting empirical analyses is related to the classical finance problem of public spending efficiency (Afonso et al., 2005). Also, the efficiency approach is of particular interest at this moment, given the current public finances' restrictions due to the persistence of the global financial crisis. This paper is inserted in the relatively new and narrow stream of the literature undertaking cross-country comparisons, besides the country-specific analysis of the higher education systems (there are many studies, since the 1970s, whose aim is to analyse the efficiency of universities in a single country, see for example the review in Worthington, (2001)). Joumady and Ris (2005), for instance, focused on a comparison among universities in different countries, using a sample of young graduates' responses to a survey. Agasisti and Johnes (2009) used data envelopment analysis for comparing the technical efficiency of English and Italian universities and found that English institutions outperform their Italian counterpart. A similar exercise has been repeated by comparing Italian universities with Spanish and German ones (Agasisti and Perez-Esparrells, 2010; Agasisti and Pohl, 2012, respectively). Studies based on the Advanced Quantitative Methods for the evaluation of the performance of a public sector research project (Bonaccorsi and Daraio, 2007) demonstrate that the performance of universities across Europe is actually very differentiated, even if the legal status among them is similar or identical and types of activities are supposed to be very homogeneous. Their interpretation is that universities react to the changes occurring in their countries by adopting different priorities and strategies (Bonaccorsi and Daraio, 2007). Wolszczak-Derlacz and Parteka (2011) also used data from AQUAMETH (in a cross-country perspective) to derive efficiency scores for 259 public higher education institutions in Europe. Their findings suggest a role for some characteristics such as economies of scale, composition of academic staff and funding sources. 
The present paper analyses longitudinal data of the two example countries for two different performance-based models, namely the performance-oriented model (number of graduates) and the activityoriented model (number of students). Data is available on all 13 Dutch and 58 Italian public universities, for a four year period. A description of the higher education landscapes in the two countries helps in defining the contexts in which universities operate. More specifically, an illustration of the funding mechanisms' main features is provided, to justify why it is expected that universities pursue different objectives in the two countries, as the two higher education systems are examples of the different groups of incentives described above. The model that is most in line with the European goal, to increase the share of higher educated people (or the specific goal of at least $40 \%$ of 30-35 year olds having completed third-level education), is the performance-oriented model, which focuses on the number of graduates as output. The problem of comparing datasets is taken into account, by very carefully putting together the datasets on the two countries and by making absolutely sure that the variables and values that are used are comparable. Furthermore, this paper attempts to account for unobservable structural differences between the countries.

The remainder of the paper is organised as follows: in the next section, the theoretical framework is presented. The following section provides some information about the higher education institutional setting in the Netherlands and Italy and the section after that describes the methodology and data. Then the results are presented and the last section contains the conclusion and discusses the policy and managerial implications of this paper.

\section{Theoretical framework}

Some economic theories consider public universities as complex organisations, which respond to incentives in ways that are related to their own objectives (reputation, maximisation of available research funds, or other institutional potential objectives) and activities (teaching and research). Public management theory adopts a similar perspective, when assuming that when policy makers actively promote their own objectives, for instance through the models for allocating public budgets to individuals or organisations, the latter react by focusing on those specific activities or outputs that are rewarded by funding formulas, especially when considering the financial rewards as supportive (Frey and Jegen, 2001). 
Public universities in Europe receive a considerable amount of public money and public funding is still their main financial source (OECD, 2011). In this perspective, it is likely that the higher education funding mechanism adopted by the government of a country has an impact on the universities' activities and performance. A stream of the literature is devoted specifically to this point, in other words, to analyse the relationship between public funding systems (incentives) and universities' behaviours. Beath et al. (2005) illustrated how funding formulas can influence the decision of universities in concentrating more on teaching or research; they show that changing the weights of funding parameters leads to different 'cultures', which give more relative importance to one of the universities' core activities than to the other. The authors explicitly acknowledge that assumptions about the prevailing 'culture' are a key aspect for any cross-country comparison. This work strongly relies upon the Del Rey (2001) model of universities' behaviour; the author makes an assumption about the institutions' objective, the maximisation of reputation or quality, also including an exogenous influence of the public funding system. Gautier and Wauthy (2007) outlined a similar framework, in which the relevant dimension is 'internal' (the incentive system to which individual academics respond). Their model shows that heterogeneous preferences about teaching and research can be accommodated into a single rewarding scheme. Their analysis underlines the importance of the ability to modify the behaviour of academic agents with incentive schemes. It is possible to make the agents more focused on improving performances; the key requirement is that the rewarding scheme explicitly provides incentives to performance (performance-based mechanisms). Johnes (2007) analysed the impact of different funding formulas on English universities' behaviour. More specifically, his paper separates the concepts of costs and efficiency, showing that a formula actually could take into account differentials, which are related to universities' activities (costs), and others that are related to institutional ability to make the most with the available money (efficiency). The author argued that the agency in charge of funding universities in England basically uses a formula rewarding the number of students recruited; and a desirable adjustment of the formula is increasing flexibility for allowing different cost structures of universities.

Overall, this literature suggests that universities' activities are indeed very much influenced by the funding scheme adopted by the government in their country. In the light of such dependence, the performances obtained by universities must be interpreted according to the different economic incentives they are subjected to. However, when countries 
commit themselves to European goals, these goals might conflict with the incentives that flow from the national funding scheme.

National uniform funding schemes tend to provide the same incentives for all universities in the country but this does not hold for universities located in different countries, which might still all be part of Europe. This is due to the fact that each national government can have its own idea of the 'socially optimal' investment in public higher education; for instance, some countries can consider it more important to increase the number of people with a tertiary education degree (graduation rates), while others can target the accessibility for students from lower socioeconomic backgrounds (equality of opportunities) and others being interested in maximising the number of students of each age cohort entering higher education overall (entry rates). From these potentially heterogeneous objectives, differences stem from incentives set through policy-making. The present paper empirically shows that a common European goal with respect to higher education is much harder to realise when countries have different incentive schemes, compared with a situation in which incentives are harmonised as part of the common European policy. To do so, the performances (efficiency) of universities are compared in a cross-country approach, taking into account these differences in incentives. The main theoretical argument is that such exercise will most likely lead to confounding results if failing to properly consider differences in underlying objectives or incentives. Facing this challenge, this study focuses on universities operating in two different European countries (Italy and the Netherlands), which are characterised by different policy régimes and priorities, reflected in their different budgetary mechanisms; such differences are expected to affect universities' performances in a heterogeneous fashion.

Let us consider that there are $\mathrm{n}$ universities in each of two countries $\mathrm{A}$ and $\mathrm{B}$, so that $\mathrm{A}_{\mathrm{i}}$ indicates the $i$-th university in country $\mathrm{A}(\mathrm{i}=1,2, \ldots$ $\mathrm{n})$ and $\mathrm{B}_{\mathrm{i}}$ the $i$-th university in country $\mathrm{B} . \mathrm{A}_{\mathrm{i}}$ and $\mathrm{B}_{\mathrm{i}}$ 'react' to the incentives stimulated by the national government through the funding model; if it is the case, and to the extent that these incentives are different in the two countries, the observed performances of the universities operating in the two countries are very hard to compare $\left(\mathrm{Eff}\left[\mathrm{A}_{\mathrm{i}}\right] \neq \mathrm{Eff}\left[\mathrm{B}_{\mathrm{i}}\right]\right)$ and are dependent on the specific parameters (objectives) included in the funding formulas. At the same time, it can be the case that each public university, in each country, is more (less) efficient in its operations, so that the observed performance level can be higher (lower) when compared to the other universities operating in the same country (so, Eff $\left[\mathrm{A}_{1}\right] \neq \operatorname{Eff}\left[\mathrm{A}_{2}\right] \neq \ldots \operatorname{Eff}\left[\mathrm{A}_{\mathrm{n}}\right]$ ). Indeed, the literature 
shows that public organisations could be more or less efficient due to their management practices (Andrews et al., 2012). Thus, efficiency differentials are analysed between universities in two countries, assuming that:

- part of the differences in efficiency is related to different managerial efficiency (within-country variation);

- another part of the differences between universities is due to different policy landscapes (national budgetary rules), which provide different incentives to comply with (between-countries variation).

- It is important to note that the country with incentives related to increasing the number of graduates (the Netherlands) is more in line with the pursuing of EU2020 targets. At the same time, however, the analysis presented in this paper considers not only the graduation rate as a target (as EU2020 does) but also the 'cost' for obtaining this result (cost-efficiency perspective).

Given the two different landscapes of the higher education systems in the Netherlands and Italy (discussed in the next section) and in the light of the theoretical framework depicted above, it is likely that the relative performance (efficiency) of Italian and Dutch universities is strongly influenced by the funding policy perspective adopted in the empirical analysis. The assumption is that Dutch universities will perform more in line with the EU2020 goals and will try to minimise 'cost per graduate', since their funding system is mainly based on the number of graduates. On the other hand, universities in Italy are most likely more focused on minimising 'cost per student', as their (public) funding system is based on the number of students. This study considers that the heterogeneity in the objectives can be modelled as the universities are following two different sets of incentives, which can be better described if considering two different empirical analyses: one in which the key indicator is the ratio between outputs obtained (graduates) and money invested ('cost for performance' model) and one in which the numerator is the number of students ('cost for activity' model).

Thus, the following two hypotheses are formalised:

$\mathrm{H}_{1}$ : When empirically analysing the efficiency of Italian and Dutch universities using the 'cost for performance' model, Dutch universities are more efficient than Italian universities and are more likely to reach the EU2020 target of more university graduates.

$\mathrm{H}_{2}$ : Italian universities are expected to be more efficient when using the 'cost for activity' model specification, given their funding system. 


\section{Institutional setting in Italy and the Netherlands}

Dutch higher education consists of two parts: university education on the one hand and higher professional education on the other hand. Higher professional education schools (HBO-schools) prepare students for professional practice and usually offer a four-year bachelor programme. Universities mainly offer a three-year bachelor programme and a one- or two-year master programme. Apart from that, universities devote a large share of their time and funds to research, unlike higher professional education schools. In this paper, only the 13 public universities in the Netherlands are considered. The choice of focusing exclusively on universities is due to the necessity of comparing performances between the Netherlands and Italy. Indeed, as Italy does not have a two-tier system (academic and vocational), all the higher education institutions are formally universities; as a consequence, for pursuing the comparability objective, there was no other choice than to leave HBOs out of the analysis. The 13 universities are rather homogeneous and offer very comparable quality and choice with respect to programmes. Most universities offer all kinds of disciplines, whereas a few focus on technical disciplines and one is mainly an agricultural university. The universities also have similar quality and quantity of research.

After the Bologna process, the bachelor-master curriculum was introduced from 2002 on. Students in the 'old' programme, which started in or before 2001, were allowed to finish their study in the programme in which they started. From 2002 on, it was only possible for new students to enter a bachelor programme. As the 'old' programme took four or five years, and on average students are delayed between 0.5 and one year, university statistics on students include 'old system' students until at least 2008 or 2009 . There have been no changes in the number of universities and no shocks in student numbers during the years of the analysis.

Although the Dutch university system does not have a specific selection system for new students, apart from the prerequisite of finishing preuniversity secondary education and, for some studies, graduation in specified subjects, many universities have a so-called 'binding study advice' after the first year, which only allows a student to continue if he or she obtained a specified amount of credits during the first year. This system ensures the early exit of students who are very unlikely to obtain a diploma at the end of the programme. This saves money but also ensures better statistics with respect to the ratio of new entrants compared to the number of diplomas. Given that a combined bachelor and master study takes four years to complete, one would expect that the number of 
graduates is about 25 per cent of the total amount of students. However, this share is even larger than 25 per cent in 2009 (Figure 1), and this is likely to be due to the 'binding study advice', because it preselects candidates with a higher chance of graduation. Advising students at the beginning of the first year makes each cohort of students particularly efficient in reaching a diploma within four years.

Funding of universities happens via three streams. The first stream is the funding from the government. The second stream is funding from project-based public research funds from public research organisations in the Netherlands (such as NWO and KNAW). The third stream is the private funding of teaching and research. The first stream is funded by the government and consists of funds for both teaching and fundamental research. The amount for the teaching part consists of: (1) a fixed amount, which is a basic fee based on historical graduation numbers; (2) diploma-based allocation; and (3) new entrants based allocation. Twoyear averages are used for the number of diplomas and number of new entrants to average out outliers. The fixed amount and diploma-based amount account for almost 80 per cent of the total amount of this teaching part of the first stream; the remaining 20 per cent consists of the new-entrants-based allocation. The research part consists mainly of

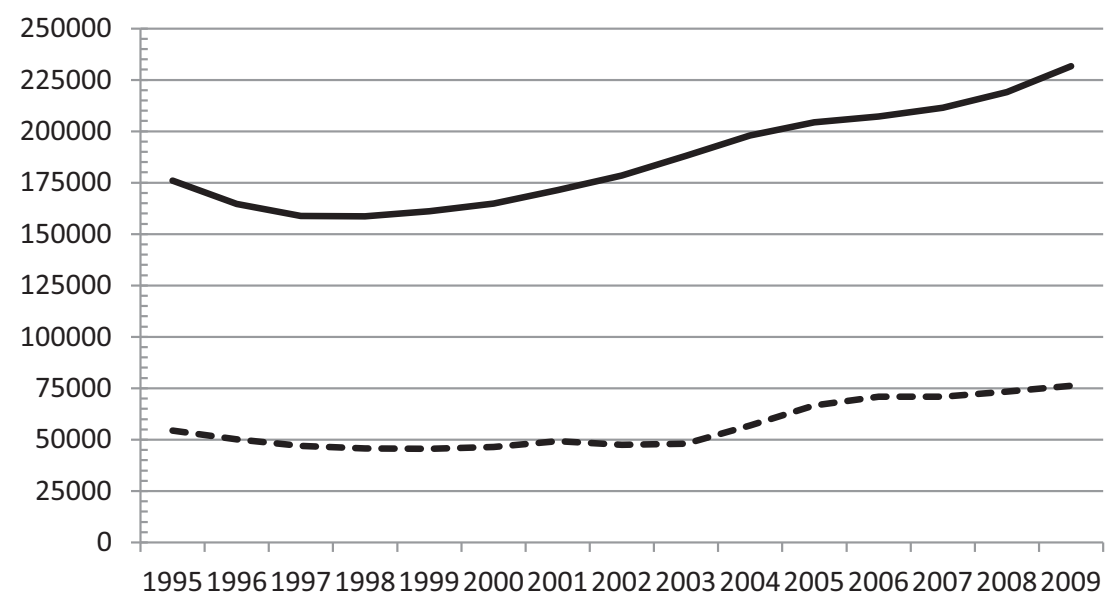

Students - - Graduates

Figure 1 The number of students and graduates in the Dutch higher education system, 1995-2009 (Source: Authors own calculations, based on public data from VSNU, the Netherlands) 
another fixed amount per university, allocation of $\mathrm{PhD}$-certificates and fixed amounts for research schools (Jongbloed and Salerno, 2003; Weert de and Boezerooy, 2007). The funding of Dutch universities is very performance based. The total amount of funding by the government is lump-sum funding; universities are free to spend the funds as they please.

Italy has one of the largest higher education systems in Europe but at the same time it has been considered as one of the most inefficient and ineffective (Lambert and Butler, 2006). Italian higher education is constituted exclusively by universities, meaning that there are not vocationally oriented institutions; among the 78 universities, 61 are public and 17 private. This paper focuses only on the public universities. The system is affected by well-known problems, among which high drop-out rates is the most relevant. According to the Ministry of Education, the drop-out rate is around 18 per cent just between the first and second year in 2009-10 (MIUR, 2011). To address these problems, and the excessive duration of studies (in 2001, only 25 per cent of students graduated before they are 25 years old), the Italian university system introduced major reforms, initiated in 2001 by the so called 'Bologna Process', which is the process of changing university curricula in several European countries, with the aim of increasing the effectiveness and efficiency of undergraduate and postgraduate teaching (Agasisti and Pohl, 2012). The 'Bologna Process' changed the traditional courses, based on a unique degree, obtained after four or five years (Laurea), to a Bachelor-Master structure (bachelor of three years, master of two years). The number of students increased in the years immediately after the introduction of Bologna, to a maximum of 1.8 million in 2003 and are stable in recent years at about 1.7 million (Figure 2). The number of graduates is increasing as well (to almost 300,000 in 2009), even though a part of this increase is still related to 'old system' students who switched to the BA-MA structure.

Italian universities are free to set their own student fees, even though their amount is partially constrained by a national regulation; however, student fees represent just a small part of universities' income (around $10 \%)$. For the remaining part, universities are mostly funded directly by the Ministry of Education, which also has the major responsibility for regulating higher education (for example, staff salaries, rules to activate courses). Since 1993, the budget provided by the Ministry (called Fondo di Finanziamento Ordinario (FFO)) is in the form of a lump-sum budget, which can be managed autonomously by each university. FFO accounts for about 60 per cent of the total universities' income. 


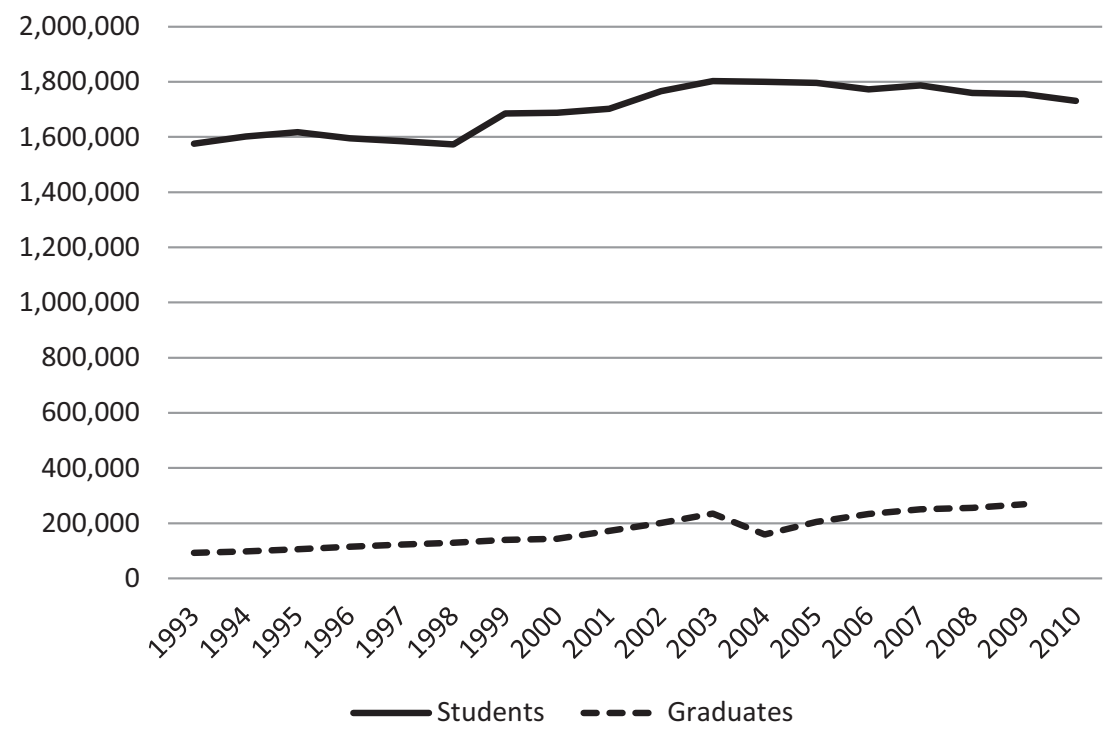

Figure 2 The number of students and graduates in the Italian higher education system, 1993-2010, (Source: Authors own calculations, based on public data from Ufficio Statistico MIUR, Italy)

Moreover, the FFO has been traditionally allocated on the basis of historical costs: each university received the amount obtained in the year before; as a consequence, such mechanism did not provide incentives for performance nor did it align with input dimensions (the number of students). From 2004, the Ministry of Education adopted a formulabased model to allocate public money among universities; the new model takes into account some inputs and performance indicators. Basically, the formula considers the number of students and (partly) graduates, so the resulting allocations are proportional to the size of student population. Therefore, only a minor part of the overall budget is allocated through the formula, while the majority is still related to historical expenditures (Paba, 2012).

In Italy, there is not a specific recurrent fund for research. Universities receive $\mathrm{FFO}$ as a unique block grant and can use it for both teaching and research activities. In general, this fund reflects historical costs and the size of universities - as measured by professors and students; as a consequence, there is not a specific incentive provided by the Ministry 
through formula funding for research. Additional research funding is collected by participating in tenders, as well as realising applied research commissioned by third parties.

\section{Methodology and data}

\section{Methodology}

This paper analyses higher educational institutions that yearly receive a (public) budget from the government and receive research grants (depending on how successful they are to apply for grants) in order to perform their teaching and research activities, which in turn lead to teaching and research outputs. The budget received from the government is only related to teaching activities, whereas the research grants are usually not sufficient to cover all research activities. Hence, it is assumed that universities try to minimise their costs in order to produce as much output as possible so they can maximise the benefit from the finances they receive (and can also cross-subsidise research). The conversion from inputs (costs, expenditures) into outputs (research and teaching) is usually analysed by an efficiency framework. Efficiency is defined as the ratio between (weighted) outputs and (weighted) inputs; weights are used to consider many inputs and outputs simultaneously.

This paper relies on the idea of technical (or productive) efficiency (Farrell, 1957), meaning the ability of a university to transform inputs into outputs. Efficient universities are those for which the ratio between outputs and inputs is highest: in other words, they produce the maximum level of output given the available inputs. Efficient universities are then used as a 'benchmark' to compare with other universities; the latter are defined as 'inefficient' and the degree of inefficiency is calculated as a distance from 'best-practice' institutions.

For the analysis of this cost minimisation model, stochastic frontier analysis (Kumbhakar and Lovell, 2000) is used. Stochastic frontier analysis derives information about 'best practice', that is minimising costs for obtaining the observed output levels; and efficiency is defined as the ability to produce at such minimum cost. With stochastic frontier analysis, a frontier is estimated on the relation between inputs and outputs. This can, for example, be a linear function, a quadratic function or a Translog function. This paper uses a Translog function (for a discussion on the different function forms, see Agasisti and Johnes, 2009, p. 1368), which allows for non-linear causalities, compared with the more simple Cobb-Douglas function. As all universities invest in 
both outputs (graduation numbers and research grants), the second desiderata of Baumol et al. (1982) does not pose as a problem. The efficient universities ('best practices') lie on the frontier, which represents full efficiency. All other universities are located above the frontier, as they are not operating at minimum costs. The distance between a university's location and the frontier is the decrease in costs that is still possible for this university, given the current output.

The Translog function does not only include inputs and outputs but also country and year dummies, in order to correct for heterogeneity between countries and differences between years. For the estimation of the Translog function, maximum likelihood methods are used, which allow observation-specific estimates of technical efficiency to be obtained (Jondrow et al., 1982). The efficiency term is constrained to be constant over time; it seems the most reasonable assumption given that the time-period that is analysed is quite short (four years); significant changes in the relative efficiency of universities are likely to occur more in the medium than in the short run, given that input levels and 'production technology' must be changed accommodating the spaces for higher efficiency.

Therefore, the robustness of the results and the reliability of this assumption is checked by also performing a time-varying version of the stochastic frontier analysis. The results are available on request from the authors; they are qualitatively and quantitatively consistent with those that are presented in the next section, which includes the year dummy.

The Translog cost function is the following:

$$
\begin{aligned}
\ln (C)= & a_{0}+\sum_{i=1}^{m} b_{i} \ln \left(T_{i}\right)+\sum_{i=1}^{n} c_{i} \ln \left(R_{i}\right)+\frac{1}{2} \sum_{i=1}^{m} \sum_{j=1}^{m} b_{i j} \ln \left(T_{i}\right) \ln \left(T_{j}\right) \\
& +\frac{1}{2} \sum_{i=1}^{n} \sum_{j=1}^{n} c_{i j} \ln \left(R_{i}\right) \ln \left(R_{j}\right)+\sum_{i=1}^{m} \sum_{i=1}^{n} e_{i j} \ln \left(T_{i}\right) \ln \left(R_{i}\right)+\varepsilon
\end{aligned}
$$

Where $\mathrm{C}$ are the total costs, $\mathrm{T}_{\mathrm{i}}$ denotes the teaching output of type $\mathrm{i}$ and $\mathrm{R}_{\mathrm{i}}$ denotes the research output of type $j$.

\section{Data}

There is a long history in literature of efficiency studies in higher education and a long experience about the inputs and outputs that are being used in such analyses. Two types of outputs are mainly used in these studies: first, outputs that are related to the teaching activities of higher education; second, outputs that are related to research activities, 
such as publishing and applying for research grants. Furthermore, some studies use only teaching outputs (Stevens, 2005; Agasisti and Salerno, 2007; Abbott and Doucouliagos, 2009) or only research outputs (Adams et al., 2005; Cherchye and Vanden Abeele, 2005; Groot and García-Valderrama, 2006). Other studies use a combination of the two, such as Flegg et al. (2004), Johnes et al. (2005) and Worthington and Lee (2008). Specifications of these different outputs are, for instance, scientific publications, number of undergraduate, graduate or $\mathrm{PhD}$ students, income from research and income from grants. Studies that combine these two types of outputs often focus on the existence of economies of scope (De Witte et al., 2012). Some studies deviate from the standard outputs, as described above. These studies use, for example, quality and reputation of the higher education institutes as output (Dawson et al., 2009). With respect to inputs, there is also a large distinction between studies that include costs (Athanassopoulos and Shale, 1997; Johnes, 2006, 2008; Worthington and Lee, 2008) and studies that do not (Adams et al., 2005; Ferrari and Laureti, 2005).

However, in general there is an agreement on using costs or expenditures as inputs and teaching (number of students or graduates) and research (grants) as outputs. Taking this into account, the total expenditures (corrected for inflation) are used as inputs. Graduates are used as output, as well as research grants (corrected for inflation), which can be considered both an activity and performance. It could be argued that research grants can be considered more an input than an output, as they represent available resources to realise research outputs. However, for many years, this indicator is used in efficiency analyses as a proxy for the universities' reputation in research, under the hypothesis that this amount reflects the ability to attract competitive funds, in other words, research quality. Previous studies about institutions' efficiency indeed use this variable for measuring research outputs, as described in the methodological essay by Johnes (2004). Unfortunately, the information on publications or citations is not available and therefore cannot take these into account as an output.

Data were collected by statistical agencies of the two countries and refer to a four-year timespan (from 2005-06 to 2008-09). There are large differences in the average size of the universities (Table 1). The average Dutch university is about two-thirds the size of an Italian university. The minimum and maximum values show that there is also a much larger variation in university size in Italy than in the Netherlands. The ratio between bachelor and master students is very similar in both countries; there are more than twice as many bachelor students as master 
TABLE 1

Descriptive statistics universities, per country, year 2008-2009a

\begin{tabular}{|c|c|c|c|c|}
\hline Variable & Mean & Std. Dev. & Min & Max \\
\hline \multicolumn{5}{|c|}{ Italy $(n=61)$} \\
\hline Total number of students & 26,547 & 22,581 & 612 & 120,189 \\
\hline Bachelor students & 18,149 & 14,814 & 482 & 78,194 \\
\hline Master students & 8,398 & 7,927 & 130 & 41,995 \\
\hline $\mathrm{PhD}$ candidates & 603 & 555 & 8 & 2,829 \\
\hline Number of staff & 991 & 891 & 42 & 4,752 \\
\hline Bachelor graduates & 2,450 & 2,020 & 93 & 9,820 \\
\hline Master graduates & 1,408 & 1,328 & 34 & 6,267 \\
\hline $\mathrm{PhD}$ graduates & 191 & 260 & 5 & 1,801 \\
\hline Research grants (Euros) & $23,700,000$ & $24,000,000$ & 107,853 & $92,200,000$ \\
\hline Expenditures (Euros) & $219,000,000$ & $188,000,000$ & $16,500,000$ & $914,000,000$ \\
\hline Expenditures per student & 9,092 & 7,180 & 3125 & 61,148 \\
\hline \multicolumn{5}{|c|}{ Netherlands $(\mathrm{n}=13)$} \\
\hline Total number of students & 16,856 & 7,776 & 5,157 & 29,276 \\
\hline Bachelor students & 12,191 & 6,174 & 2,943 & 21,779 \\
\hline Master students & 4,666 & 1,919 & 2,093 & 7,833 \\
\hline PhD candidates & 594 & 212 & 268 & 1,024 \\
\hline Number of staff & 1,142 & 422 & 581 & 2,033 \\
\hline Bachelor graduates & 2,223 & 1,219 & 479 & 4,367 \\
\hline Master graduates & 2,083 & 899 & 843 & 3,465 \\
\hline PhD graduates & 258 & 97 & 85 & 417 \\
\hline Research grants (Euros) & $95,100,000$ & $39,800,000$ & $54,600,000$ & $186,000,000$ \\
\hline Expenditures (Euros) & $409,000,000$ & $151,000,000$ & $176,000,000$ & $706,000,000$ \\
\hline Expenditures per student & 26,978 & 9,797 & 14,785 & 48,290 \\
\hline
\end{tabular}

${ }^{a}$ Research grants and expenditures are corrected for inflation and expressed in $2008 €$.

students: in the dataset, old-system students and graduates are considered master students and master graduates in the Netherlands. The average numbers of $\mathrm{PhD}$ candidates is also very similar in the two countries; although the minimum and maximum show that there are huge differences between universities within Italy. Interestingly, the average number of staff is larger in the Netherlands compared with Italy, despite the lower student numbers. The number of staff per student is therefore much higher in the Netherlands. The same interesting differences can be seen with respect to the bachelor, master and $\mathrm{PhD}$ graduates. The expenditures and research grants are also much higher in the Netherlands than in Italy.

While the number of students was much higher in Italy, the graduation totals are very similar for bachelor students and even higher for master and PhD students in the Netherlands. These numbers might 
already reflect the differences in policy and funding in the two countries (between-countries differences), as well as a different average level of universities' efficiency (within-country differences).

\section{Results}

The 'cost for performance' model

Part A of Table 2 presents the results of the stochastic frontier analysis cost function analysis, in which the Italian and Dutch universities are

\section{TABLE 2}

Results from the empirical analysis: 'cost for performance' model

Panel A. Regression outputs

Cost for Performance

\begin{tabular}{|c|c|c|}
\hline $\begin{array}{l}\text { Number of obs. }= \\
\text { Number of groups }= \\
\text { Wald chi2 (18) } \\
\text { Log likelihood }=\end{array}$ & $\begin{array}{r}283 \\
73 \\
1728.630 \\
83.026\end{array}$ & \\
\hline & Coeficient & $Z$ \\
\hline $\begin{array}{l}\text { Country dummy (Italy = 1) } \\
\text { jr } 2006 \text { dummy } \\
\text { jr } 2007 \text { dummy } \\
\text { jr } 2008 \text { dummy }\end{array}$ & $\begin{array}{l}-0.205 \\
-0.138 \\
-0.178 \\
-0.216\end{array}$ & -3.050 \\
\hline Log bachelor graduates & 0.871 & 1.420 \\
\hline log master graduates & -0.330 & -0.940 \\
\hline log phd graduates & 0.205 & 0.470 \\
\hline log research grant & -0.151 & -0.830 \\
\hline log bachelor graduates squared & 0.005 & 0.100 \\
\hline log master graduates squared & 0.072 & 2.470 \\
\hline log research grant squared & 0.020 & 2.930 \\
\hline log phd graduates squared & 0.076 & 2.800 \\
\hline $\log$ bachelor graduates ${ }^{\star} \log$ master graduates & -0.154 & -1.250 \\
\hline log bachelor graduates ${ }^{\star} \log$ research grants & -0.077 & -1.140 \\
\hline log master graduates ${ }^{\star} \log$ research grants & 0.061 & 1.340 \\
\hline log bachelor graduates $\star \log$ phd graduates & 0.189 & 1.690 \\
\hline log master graduates $\star \log$ phd graduates & -0.128 & -1.340 \\
\hline $\log$ research grants $\star \log$ phd graduates & -0.116 & -2.280 \\
\hline Constant & 13.564 & 7.030 \\
\hline $\mathrm{Mu}$ & 0.630 & 0.840 \\
\hline ln sigma2 & -3.063 & -25.110 \\
\hline ilgtgamma & 0.238 & 0.930 \\
\hline
\end{tabular}

Panel B. Efficiency scores

\section{Cost for Performance}

\begin{tabular}{lccc}
\hline Country & $\mathrm{n}$ & Mean & St.dev \\
\hline Italy & 244 & 0.534 & 0.101 \\
Netherlands & 52 & 0.555 & 0.089 \\
\hline
\end{tabular}


considered together in the same model. To correct for structural differences between the countries (such as personnel salaries) a country dummy is included in the analysis, as well as time dummies (reference year: 2008-09); where the negative signs associated with the relative estimated coefficients mean that expenditures are growing over time. The coefficient indicating inefficiencies, $\ln ($ sigma 2$)$, is also statistically significant and indicates the presence of significant inefficiency; that is, universities are not operating with a cost-minimising behaviour, which also shows in the efficiency scores of part B of Table 2. Part B of Table 2 shows the mean and the standard deviation of the efficiency of the universities per country, which are averages of all the universities for all years. These results underline the expectations that were presented in the theoretical framework, in other words that Dutch universities perform (slightly) better at the 'cost for performance' model (average efficiency is 55 per cent, while for Italy this is 53 per cent), which is in line with the incentives based on which money is distributed. The standard deviation of universities' efficiency scores (by country) is slightly lower for Dutch universities, implying that Dutch universities are more heterogeneous with respect to the amount of graduates. Italian and Dutch universities have similar numbers of students (see also the descriptive statistics section) but the ratio of graduates to the number of students enrolled is much higher in the Netherlands and this causes the difference in average efficiency between universities from the two countries. Nevertheless, because the difference in expenditures between the Netherlands and Italy is very large (the former are much richer than the latter), Italian universities are still considered almost as efficient as Dutch universities, even though their number of graduates is much lower (Figure 3). The efficiency scores for the 61 Italian and 13 Dutch universities, under the hypothesis of the 'cost for performance' model shows the relative position of Dutch universities, as efficiency does not seem much better than Italian universities in absolute terms, despite the confirmation that Dutch institutions perform much better. Indeed, it is important to underline here that, given the models' assumptions, it does not mean that Italian universities perform almost the same as Dutch ones. Actually, the results are driven by the hypothesis that universities minimise the costs for their performances; in this context, fewer resources available for Italian universities make them similarly 'efficient', even though they actually 'perform' worse. A further element that clarifies this point is that the ratio of transformation of a student into a graduate is much higher for Dutch universities (the ratio 'students to graduates' is $7: 1$ in Italy vs. $4: 1$ in the Netherlands). In other words, 


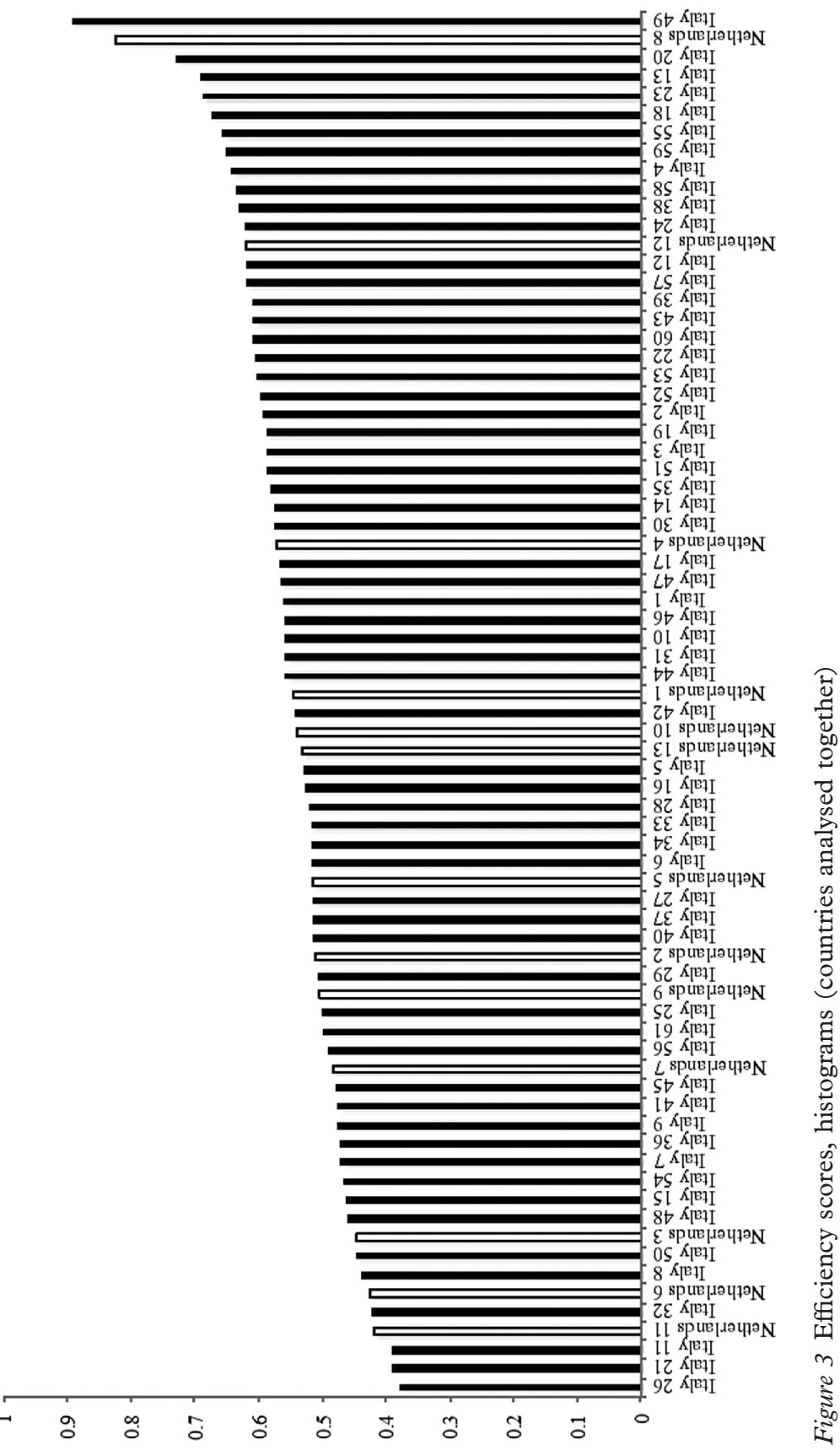


Italian universities are able to spend less money for a student or graduate than their Dutch counterparts but the cost of transforming a student in a graduate is lower for the latter.

\section{The 'cost for activity' model}

When the countries are compared in the same analysis for the cost for activity model, again inefficiencies are found and expenditures have grown over time (Table 3 Panel A). Furthermore, the impact of the research grants, the only comparable variable, is similar as for the cost for performance model. Italian universities are much more efficient than their Dutch counterparts, when the number of bachelor and master students is used as outputs instead of number of graduates (Table 3 Panel B). This shows once again that the incentives in Italy are not towards producing graduates but towards accepting as many students as possible.

This policy perspective is very inefficient from a European point of view, in which an increase in the number of graduates is valued much more (and where the increase of students entering higher education reduces graduation rates if they do not succeed, all else being equal). This discrepancy in European and national objectives emphasises the necessity of EU coordination once more.

\section{Concluding remarks}

This paper studied the feasibility of the European EU2020 goal of increasing the number of higher education graduates, considering the large differences in incentives and funding schemes between countries in Europe. This is analysed by conducting an efficiency analysis on 13 Dutch and 58 Italian public universities. An efficiency model is considered, which is in line with the EU2020 goal with respect to higher education and underlined the argument (that not all countries have the incentives to realise these goals) with efficiency results from a different model with the focus on number of students instead of number of graduates.

The findings show that the relative efficiency of Italian and Dutch universities is strongly influenced by the policy perspective adopted. In other words, the type of funding (and its rules) that is used for financing public universities in a country mainly determines the performance type that is aimed for. If the priority is to realise the European goals and minimise resources employed for obtaining a high number of graduates, Dutch universities turn out to be more efficient. However, Italian universities are much more efficient if the priority is to minimise the 


\section{TABLE 3}

Results from the empirical analysis: 'cost for activity' model

Panel A. Regression outputs

Cost for activity

Number of obs. $=$

Number of groups $=$

Wald chi2 (18)

284

74

Log likelihood $=$

1741.980

87.120

\begin{tabular}{|c|c|c|}
\hline & Coeficient & $Z$ \\
\hline Country dummy (Italy $=1$ ) & -0.544 & -7.170 \\
\hline jr 2006 dummy & -0.080 & -2.480 \\
\hline jr 2007 dummy & -0.091 & -2.340 \\
\hline jr 2008 dummy & -0.093 & -2.110 \\
\hline Log bachelor students & -2.117 & -2.510 \\
\hline $\log$ master students & 0.568 & 1.280 \\
\hline log phd students & 1.502 & 2.240 \\
\hline $\log$ research grant & -0.606 & -2.320 \\
\hline log bachelor students squared & 0.217 & 3.260 \\
\hline log master students squared & 0.029 & 0.990 \\
\hline log research grant squared & 0.030 & 4.250 \\
\hline log phd students squared & 0.108 & 2.920 \\
\hline $\log$ bachelor students ${ }^{\star} \log$ master students & -0.229 & -1.540 \\
\hline $\log$ bachelor students ${ }^{\star} \log$ research grants & 0.087 & 1.190 \\
\hline log master students ${ }^{\star} \log$ research grants & -0.045 & -1.060 \\
\hline $\log$ bachelor students ${ }^{\star} \log$ phd students & -0.450 & -2.540 \\
\hline $\log$ master students ${ }^{\star} \log$ phd students & 0.183 & 1.750 \\
\hline $\log$ research grants $\star \log$ phd students & -0.144 & -2.490 \\
\hline Constant & 22.347 & 7.380 \\
\hline $\mathrm{Mu}$ & 0.345 & 2.260 \\
\hline $\ln$ sigma2 & -2.938 & -12.260 \\
\hline ilgtgamma & 0.551 & 1.370 \\
\hline
\end{tabular}

Panel B. Efficiency scores

\begin{tabular}{llll}
\hline & \multicolumn{3}{c}{ Cost per Activity } \\
\hline Country & $\mathrm{n}$ & Mean & St.dev \\
\hline Italy & 244 & 0.725 & 0.112 \\
Netherlands & 52 & 0.671 & 0.087 \\
\hline
\end{tabular}

costs for obtaining a given level of activity, such as the number of students. The main policy consequence of the findings is that it will be hard to realise European goals if not all countries have an incentive scheme that is in line with these goals, especially because the European Union is highly dependent on national policies in achieving the joint goals, as discussed in the introduction. Another policy consequence is that one cannot easily compare universities from different European 
countries if they differ largely in their institutional settings and incentives. If countries are not willing to change national policies in the same direction, jointly set targets are merely empty targets that will never be reached.

Note that, in this paper, a very clear set of objectives stated by the European Commission is assumed, while this is not exactly the case for all objectives. As already briefly discussed in the introduction, in reality, European policy papers contain nuance statements about the various objectives and the statements do not always explain the ultimate policy goals very well. Nevertheless, as said, some specific targets were set (for instance, 'at least $40 \%$ of 30-34-year-olds completing third level education') and this helps in setting the scene for comparing the results obtained by higher education systems even if they are very different from each other.

To put the results in perspective, it is important to note that in this paper one (major) aspect of the policies that determine university performance is chosen. However, there are other policies that are also relevant for determining efficiency (in addition to public funding systems) that are worth mentioning as well as an explanation for differences in efficiency results between different countries. For instance, it can be the case that differences in college fees creates different incentives (even within countries) that can complement or challenge the objectives set by governments and the instruments that are created for pursing them. Also, the autonomy that universities have in recruiting academic staff (and defining salary levels) can also explain part of the variability in the output indicators that are used (for instance, the amount of research grants); and the average socioeconomic condition of students can influence the indicators about enrolment and graduation rates (for instance, because it has an effect on the necessity for them to work while studying or not). All these factors, which deal with miscellaneous characteristics of the higher education system, well beyond the technicalities of the funding system, are not explored in this paper, mainly because of the lack of adequate information on these factors. At the same time, it can be concluded that from the economic-driven analysis proposed in this paper, there are indications that support the view that national funding arrangements is for sure one of the factors influencing universities' efficiency.

The results imply that a common European goal with respect to higher education is much harder to realise when countries have different incentive schemes, compared with a situation in which incentives are harmonised as part of the common European policy. This also implies that comparing university performance in the current situation, for 
example by means of European rankings, is not fair, as universities have different incentives. Strengthening higher education will continue to be a matter of national policy makers, as long as systems within Europe are not comparable, even though the EU has set a common goal for Europe. In this context, a more relevant role of European and international authorities in regulating higher education policies should pass through a rethinking of fiscal and funding policies. If the European Union, for instance, would convince its members to choose one type of funding model and invest money in developing common activities across Europe, then it should be possible to compare the efficiency of universities in managing these resources and it would be more feasible to accomplish European goals such as increasing the number of higher education graduates. Without these common policies, it is not credible to assume that universities operating in systems with strikingly different objectives can simply be compared based on their performance (except with efficiency analysis), as is done in Europe at the moment, or will have the same goals, which coincide with the current European goals.

It is important to underline that this paper shows the existence of a correlation between the funding model of each country and its performance (as measured through the efficiency concept). However, the empirical approach used here, as well as the available data, did not allow us to investigate the specific characteristics of this relationship: this is an interesting point for potential further development. In addition, for future research it would be interesting to study the effect of changing funding schemes and incentives in countries that have (other) policies that do not support these EU2020 goals.

\section{Acknowledgements}

The authors are grateful to the Editor and two anonymous referees for the useful comments. Any errors are the authors' solely responsibility.

\section{References}

Abbott, M. and Doucouliagos, C. (2009) Competition and Efficiency: Overseas Students and Technical Efficiency in Australian and New Zealand Universities. Education Economics, 17(1), pp. 31-57.

Adams, J. D., Black, G. C., Clemmons, J. R. and Stephan, P. E. (2005) Scientific Teams and Institutional Collaborations: Evidence from US Universities, 1981-1999. Research Policy, 34, pp. 259-285.

Afonso, A., Schuknecht, L. and Tanzi, V. (2005) Public Sector Efficiency: an International Comparison. Public Choice, 123, pp. 321-347.

Agasisti, T. and Johnes, G. (2009) Beyond Frontiers: Comparing the Efficiency of Higher Education Decision-Making Units across More Than One Country. Education Economics, 17(1), pp. 59-79. 
Agasisti, T. and Perez-Esparrells, C. (2010) Comparing Efficiency in A Cross-Country Perspective: the Case of Italian and Spanish State Universities. Higher Education, 59, pp. 85-103.

Agasisti, T. and Pohl, C. (2012) Comparing German and Italian Public Universities: Convergence Or Divergence in the Higher Education Landscape. Managerial and Decision Economics, 33(1), pp. 71-85.

Agasisti, T. and Salerno, C. (2007) Assessing the Cost Efficiency of Italian Universities. Education Economics, 15(4), pp. 455-471.

Andrews, R., Boyne, G. A. and Walker, R. M. (2012) Overspending in Public Organizations: Does Strategic Management Matter? International Public Management Fournal, 15(1), pp. 39-61.

Athanassopoulos, A. D. and Shale, E. (1997) Assessing the Comparative Efficiency of Higher Education Institutions in the UK by Means of Data Envelopment Analysis. Education Economics, 5(2), pp. 117-134.

Baumol, W. J., Panzar, J. C. and Willig, R. D. (1982) Contestable Markets and the Theory of Industry Structure. San Diego, CA: Harcourt Brace Jovanovich.

Beath, J. A., Poyago-Theotoky, J. and Ulph, D. (2005) University funding systems and their impact on research and teaching: a general framework. SSRN working paper No. 901832.

Bonaccorsi, A. and Daraio, C. (2007) Universities and Strategic Knowledge Creation: Specialization and Performance in Europe. Cheltenham: Edward Elgar.

Cherchye, L. and Vanden Abeele, P. (2005) On Research Efficiency. A Micro-Analysis of Dutch University Research in Economics and Business Management. Research Policy, 34, pp. 495-516.

Dawson, J., van Steen, J. and van der Meulen, B. (2009) Science Systems Compared: a First Description of Governance Innovation in Six Science Systems. In R. Instituut (ed.). The Hague: Rathenau Instituut.

De Witte, K., Rogge, N., Cherchye, L. and van Puyenbroeck, T. (2012) Economies of Scope in Research and Teaching: a Non-Parametric Investigation. OmegaInternational fournal of Management Science, 41, pp. 305-314.

Del Rey, E. (2001) Teaching Versus Research: a Model of State University Competition. Fournal of Urban Economics, 49(2), pp. 356-373.

EU2020 (2014) The EU's growth strategy for the coming decade. Available at: http:// ec.europa.eu/europe2020/index_en.htm. Accessed 4 November 2014.

Farrell, M. J. (1957) The Measurement of Productive Efficiency. Fournal of the Royal Statistical Society. Series A (General), 120(3), pp. 253-290.

Ferrari, G. and Laureti, T. (2005) Evaluating Technical Efficiency of Human Capital Formation in the Italian University: Evidence from Florence. Statistical Methods and Applications, 2005(14), pp. 243-270.

Flegg, A. T., Allen, D. O., Field, K. and Thurlow, T. W. (2004) Measuring the Efficiency of British Universities: a Multi-Period Data Envelopment Analysis. Education Economics, 12(3), pp. 231-249.

Frey, B. S. and Jegen, R. (2001) Motivation Crowding Theory. fournal of Economic Surveys, 15(5), pp. 589-611.

Gautier, A. and Wauthy, X. (2007) Teaching Versus Research: a Multi-Tasking Approach to Multi-Department Universities. European Economic Review, 51(2), pp. 273-295.

Groot, T. and García-Valderrama, T. (2006) Research Quality and Efficiency. An Analysis of Assessments and Management Issues in Dutch Economics and Business Research Programs. Research Policy, 35, pp. 1362-1376.

Heuse, P. and Zimmer, H. (2011) The Europe 2020 Strategy. National Bank of Belgium Economic Review, II, pp. 21-45.

Johnes, G. (2007) Funding Formulae Where Costs Legitimately Differ: the Case of Higher Education in England. Education Economics, 15, pp. 385-504. 
Johnes, G., Johnes, J., Thanassoulis, E., Lenton, P. and Emrouznejad, A. (2005) An Exploratory Analysis of the Cost Structure of Higher Education in England. Lancaster: Lancaster University Management School.

Johnes, J. (2004) Efficiency Measurement. In G. Johnes and J. Johnes (eds.), International Handbook on the Economics of Education. Cheltenham: Edward Elgar, pp. 613-742.

Johnes, J. (2006) Data Envelopment Analysis and Its Application to the Measurement of Efficiency in Higher Education. Economics of Education Review, 2006(25), pp. 273-288.

Johnes, J. (2008) Efficiency and Production Change in the English Higher Education Sector from 1996/97 to 2004/05. The Manchester School, 76(6), pp. 653-674.

Jondrow, J., Lovell, C. A. K., Materov, I. S. and Schmidt, P. (1982) On the Estimation of Technical Inefficiency in the Stochastic Frontier Production Function Model. Fournal of Econometrics, 19(2-3), pp. 233-238.

Jongbloed, B. (2008) Funding Higher Education: a View from Europe, paper prepared for the seminar Funding Higher Education: A Comparative Overview, organised by the National Trade Confederation of Goods, Services and Tourism (CNC)The Hague: Center for Higher Education Policy Studies.

Jongbloed, B. and Salerno, C. (2003) De Bekostiging van het universitaire onderwijs en onderzoek in Nederland: Modellen, thema's en trends. In CHEPS (ed.). Enschede: CHEPS, Universiteit Twente.

Jongbloed, B. W. A. and Vossensteyn, J. J. (2001) Keeping up Performances: an International Survey of Performance Based Funding in Higher Education. Fournal of Higher Education Policy and Management, 23(2), pp. 127-145.

Joumady, O. and Ris, C. (2005) Performance in European Higher Education: a NonParametric Production Frontier Approach. Education Economics, 13(2), pp. 189-205.

Kumbhakar, S. C. and Lovell, C. A. K. (2000) Stochastic Frontier Analysis. New York: Cambridge University Press.

Lambert, R. and Butler, N. (2006) The Future of European Universities. Renaissance or Decay? In C. f. E. Reform (ed.). Centre for European Reform.

Ministero dell'Istruzione, dell’Università e della Ricerca (MUIR). (2011) L'Università in Cifre, Ministry of Education, Rome.

Organisation for Economic Co-operation and Development (OECD) (2011) Education at a Glance. In OECD (ed.), Education at A Glance. Paris: OECD, pp. 1-495.

Paba, S. (2012) University Funding: a Comparison between Italy and England. Rivista Italiana Degli Economisti, 17(1), pp. 43-74.

Stevens, P. A. (2005) A Stochastic Frontier Analysis of English and Welsh Universities. Education Economics, 13, pp. 355-374.

Weert de, E. and Boezerooy, P. (2007) Higher Education in the Netherlands-Country Report. Enschede: CHEPS.

Wolszczak-Derlacz, J. and Parteka, A. (2011) Efficiency of European Public Higher Education Institutions: a Two-Stage Multicountry Approach. Scientometrics, 89, pp. 887-917.

Worthington, A. C. (2001) An Empirical Survey of Frontier Efficiency Measurement Techniques in Education. Education Economics, 9(3), pp. 245-268.

Worthington, A. C. and Lee, B. L. (2008) Efficiency, Technology and Productivity Change in Australian Universities, 1998-2003. Economics of Education Review, 27, pp. 285-298. 